УДК 663.6, 628.16.081.32, 628.16.162.1

\title{
THE USE OF NATURAL MINERALS AND ACTIVATED CARBON IN TECHNOLOGY OF WATER TREATMENT DURING BREAD KVASS MANUFACTURING
}

\author{
O. Dulka, V. Prybylskiy, A. Kutz \\ National University of Food Technologies \\ O. Kovalenko \\ Odessa National Academy of Food Technologies
}

$\quad$ Key words:
Bread kvass
Water
Water treatment
Clinoptilolite
Rock crystal
Activated carbon

Article history:

Received 06.07.2018

Received in revised form

20.07.2018

Accepted 06.08.2018

Corresponding author:

O. Dulka

E-mail:

npnuht@ukr.net

\begin{abstract}
The composition of water significantly affects the flow of the process and the main indicators of the finished drink. The quality and usefulness of the product depend on the content of its impurities. Bread kvass technology does not provide additional treatment of drinking water, except for release from mechanical impurities. Therefore, the actual development of beer and non-alcoholic food industry is the development of methods for preparing water for the production of bread kvass for the intensification of the technological process and improving the health properties of the finished product.

The effect of natural minerals and activated carbon on the preparation of water during the process of fermentation of kvass wort and indicators of bread kvass is investigated in the work. The optimum temperature of fermentation of different samples of wort is determined using Saccharomyces cerevisiae MP-10 yeast. It was established that prepared water, processed in a sequence of clinoptilolite, active carbon, rock crystal with a filtration rate of $10 \mathrm{~cm}^{3} / \mathrm{min}$. positively affects the course of the technological process. In this case, the fermentation time of the kvass wort decreases by $13 \%$ and the titratable acidity increases by $25 \%$. The increase in the acidity of the beverage allows to reduce the costs of milk or citric acid at the boiling stage accordingly. Reducing the duration of fermentation and increasing the acidity of the fermented wort provides a reduction in the cost price of the finished product.

Prepared water with the use of investigated materials reduces, as well, turbidity of the finished drink by $5 \ldots 11 \%$.

The preparation of water in the proposed method has significantly reduced the oxidation-reducing potential of water and finished product. For water, this decrease was $54 \mathrm{mV}$, and the finished product, prepared on prepared water $-106 \mathrm{mV}$. The oxidation-reduction potential of bread kvass, prepared on treated water in definite sequences of treatment with clinoptilolite, active vulcanite, rock crystal and filtering speed, was $86 \mathrm{mV}$, approaching the optimal values for human cells.

Materials of experimental research indicate the expediency of the use of rock crystal, clinoptilolite, and activated charcoal for the conditioning of water during the production of bread kvass.
\end{abstract}

DOI: $10.24263 / 2225-2924-2018-24-4-26$ 


\title{
ВИКОРИСТАННЯ ПРИРОДНИХ МІНЕРАЛІВ ТА АКТИВНОГО ВУГІЛЛЯ В ТЕХНОЛОГІЇ ПІДГОТОВКИ ВОДИ ПРИ ВИРОБНИЦТВІ ХЛІБНОГО КВАСУ
}

\author{
О.С. Дулька, В.Л. Прибильський, А.М. Куц \\ Національний університет харчових технологій \\ О.О. Коваленко \\ Одеська національна академія харчових технологій
}

На перебіг технологічного прочесу та основні показники ферментованих напоїв, зокрема хлібного квасу, суттєво впливає склад води. Від вмісту ї домішок залежить якість і корисність продукту. Технологія хлібного квасу не передбачає додаткової обробки питної води, окрім звільнення від механічних домімок. Тому актуальним питанням розвитку пиво-безалкогольноі галузі харчової промисловості є розробка способів підготовки води при виробництві хлібного квасу для інтенсифікаиії технологічного процесу $і$ і підвищення оздоровчих властивостей готового продукту.

У статті досліджено вплив природних мінералів та активного вугілля при підготовиі води на прочес зброджування квасного сусла й показники хлібного квасу. Визначена оптимальна температура бродіння різних зразків сусла при використанні дріжджів Saccharomyces cerevisiae MП-10. Встановлено, що підготовлена вода, оброблена у послідовності клиноптилоліт, активне вугілля, гірський кришталь із швидкістю фільтрування $10 \mathrm{~cm}^{3} / x в$ позитивно впливає на перебіг технологічного процесу. При иьому тривалість бродіння квасного сусла зменшується на 13\% та на 25\% збільшується титрована кислотність. Збільшення кислотності напою дає змогу, відповідно, зменшити витрати молочної або лимонної кислоти на стадії купажуванні. Скорочення тривалості бродіння та збільшення кислотності збродженого сусла забезпечує зниження собівартості готового продукту.

Підготовлена вода з використанням досліджуваних матеріалів зменшує також мутність готового напою на $5 . .11 \%$.

Підготовка води запропонованим способом дала змогу суттєво знизити окисно-відновний потенціал води і готового продукту. Для води иее зниження становило 54 мB, а готового продукту, приготовленого на підготовленій воді, 106 мВ. Окисно-відновний потенціал хлібного квасу, приготовленого на обробленій воді у визначеній послідовності обробки клиноптилолітом, активним вугіллям, гірським кришталем і швидкості фільтрування, становив 86 мB, щэо наближається до оптимальних для клітин організму людини значень.

Матеріали експериментальних досліджень свідчать про доиільність застосування гірського кришталю, клиноптилоліту, активного вугілля для кондиціювання води при виробництві хлібного квасу.

Ключові слова: хлібний квас, вода, водопідготовка, клиноптилоліт, гірський кришталь, активне вугілля.

Постановка проблеми. Основною сировиною для виробництва хлібного квасу є вода, концентрат квасного сусла, цукор, культури мікроорганізмів. 
Від вибраної раси дріжджів залежить смак та аромат напою, а також його зовнішній вигляд. Використання чистих культур мікроорганізмів для виробництва ферментованих напоїв, зокрема хлібного квасу, має суттєві переваги: забезпечення постійного складу та мікробіологічної чистоти, отримання необхідної кількості мікробної культури в оптимальних умовах [1].

У виробництві хлібного квасу застосовують сушені квасні чи хлібопекарські дріжджі або чисті культури квасних дріжджів різних рас. Ефективними расами квасних дріжджів є Р-87, К-87 та КМ-94, які дають змогу інтенсифікувати та спростити технологічний процес, досягти відмінних органолептичних і стабільних фізико-хімічних показників готового напою. Найбільш поширені з них - дріжджі раси Р-87, проте їхнім недоліком є слабка інтенсивність бродіння при підвищених температурах [2].

На перебіг технологічного процесу та основні показники готового напою суттєво впливає склад води, оскільки від іiї домішок залежить якість і корисність продукту. Однак на сьогодні додаткових вимог до води для приготування хлібного квасу немає.

Збільшення чисельності населення, стрімкий розвиток промисловості призводить до зростання водоспоживання. Наслідком цього є зміна хімічного і мікробіологічного складу питної води та ризики, пов'язані з її безпечністю.

Тож удосконалення існуючих, розробка і впровадження нових способів підготовки води при виробництві хлібного квасу, що забезпечувало б інтенсифікацію технологічного процесу та підвищувало оздоровчі властивості готового продукту є актуальним питанням подальшого розвитку пиво-безалкогольної галузі харчової промисловості.

Аналіз основних досліджень і публікацій. Згідно з даними соціологічного дослідження, проведеного компанією Health Focus International, турбота про власне здоров'я вливає на мотивацію при виборі продуктів харчування. Тому серед виробників і споживачів харчової продукції сьогодні актуальним $\epsilon$ термін «health trend» (здорове харчування), незмінним супутником якого $\epsilon$ «функціональні продукти», що сприяють зміцненню захисних сил організму людини, допомагають адаптуватись до впливу довкілля, корегують водносольовий обмін, сприяють нормалізації роботи шлунково-кишкового тракту та засвоєнню інших продуктів [3; 4].

Попит на продукти функціонального призначення у світі збільшується нерівномірно. Однією з основних груп таких продуктів, що має стрімкі темпи росту виробництва, $\epsilon$ напої [1].

Функціональними є такі напої, які, окрім здатності втамовувати спрагу та приносити насолоду, забезпечують додаткову користь для здоров'я людини. 3 таких напоїв у світі достатньо поширені безалкогольні ферментовані напої (напої бродіння), які для більшості країн є традиційними, національними. Так, хлібний квас, який готують на основі житньої сировини, є традиційним слов'янським напоєм і містить широкий спектр біологічно активних речовин.

У радянські часи хлібний квас був найбільш популярним безалкогольним напоєм. Проте з розпадом СРСР багато вітчизняних виробників збанкрутували і зникли з ринку, а виробництво квасу суттєво скоротилося. На сьогодні 
квас знову повертає свою популярність, його виробництво займає все більшу частку на ринку безалкогольних напоїв [2].

За органолептичною характеристикою хлібний квас $є$ напоєм темно-коричневого кольору з приємним кисло-солодким смаком і характерним ароматом житнього хліба. Напій одержують шляхом незакінченого комбінованого спиртового і молочнокислого бродіння. Однак на більшості підприємств 3 метою спрощення технології використовують тільки спиртове бродіння, а необхідну кислотність напою досягають внесенням молочної кислоти.

Наявність у хлібному квасі незначної кількості етанолу $(0,4 \ldots 0,5 \%$ об.) не знижує фізіологічного значення цього напою для людини. Його корисність характеризується вмістом вітамінів, органічних кислот, амінокислот, макрота мікроелементів [1;2].

У рецептурі будь-якого напою вода займає головне місце. Підприємства харчової галузі використовують воду централізованих мереж водопостачання або з артезіанських свердловин. У першому випадку вода вже приведена до кондиції питної, а в другому, що зустрічається частіше, може не відповідати такій кваліфікації. Окрім цього, до технологічної води в безалкогольному виробництві є додаткові вимоги [1;2].

Існують різні способи очищення води, одним з яких є використання механічних фільтрів із засипками природних мінералів (кварцовий пісок, гравій). Однак така обробка не повною мірою забезпечує якість підготовленої води за фізико-хімічними показниками. При кондиціюванні води для виробництва ферментованих напоїв використання фільтрування $\epsilon$ обов'язковим. Така обробка направлена тільки на звільнення води від механічних і частково органічних домішок, колоїдної зависі та осаду [5; 6]. Тому актуальним $€$ удосконалення способу механічного фільтрування води із застосуванням нових ефективних природних матеріалів, зокрема мінералів. Завдяки строго визначеним розмірам пор і внутрішніх порожнин вони $є$ ефективними сорбентами не тільки зависі, але й розчинних органічних і неорганічних речовин. Такі матеріали, зокрема гірський кришталь, мають здатність покращувати органолептичні і змінювати фізико-хімічні показники води, забезпечувати іiі структурування, що збільшує оздоровчий ефект готового напою.

Сучасні технології очищення води передбачають використання природних і штучних матеріалів для вирішення різних завдань. Для реалізації сорбційних процесів використовують, зокрема, активне вугілля та його аналоги (графітмінеральні сорбенти) [7; 8]. Для цих же цілей, а також як фільтруючий матеріал, останнім часом почали використовувати цеоліти. Їх унікальні властивості можуть бути використані в багатьох галузях промисловості. В наш час відомо більше 40 структурних видів цеолітів, найбільш розповсюдженими 3 яких є клиноптилоліт, гейландит, філліпсіт, ломоніт, морденіт, ерионіт, шабазит, анальцим. Встановлено, що природні цеоліти не поступаються штучним і при цьому їхня собівартість набагато нижча [9].

Метою статті $\epsilon$ дослідження впливу природних мінералів та активного вугілля при підготовці води на процес зброджування квасного сусла й показники хлібного квасу. 
Викладення основних результатів дослідження. У роботі використовували загальноприйняті методи досліджень для пиво-безалкогольної галузі харчової промисловості. Як об'єкти досліджень використані: вода питна із централізованого водогону м. Львова згідно з ДСанПіН 2.2.4-171-10, активне вугілля Silcarbon, гірський кришталь і клиноптилоліт згідно з чинною нормативною документацією, концентрат квасного сусла, цукор, дріжджі Saccharomyces cerevisiae МП-10, готовий квас згідно з ДСТУ 4069.

Обробку води проводили клиноптилолітом, гірським кришталем та активним вугіллям в лабораторних умовах зі швидкістю фільтрування $10 \mathrm{~cm}^{3} /$ хв. Як контроль використовували необроблену питну воду. Після обробки вміст загального заліза зменшився у 5 разів (3 0,05 до 0,01 мг/дм ${ }^{3}$ ), загальна жорсткість на $75 \%$ ( 4,5 до 1,1 мМоль/дм ${ }^{3}$ ), перманганатна окиснюваність у 9 разів ( 34,0 до 0,5 мг $\mathrm{O}_{2} /$ дм $^{3}$ ). Як контроль використовували необроблену воду.

Відомо, що на тривалість бродіння впливають багато факторів. Головними 3 них є: початкова концентрація мікроорганізмів у суслі та їх фізіологічна активність, температура бродіння, фізико-хімічні показники води.

Для дослідження впливу води на процес бродіння готували чотири зразки квасного сусла:

- зразок №1 - сусло на необробленій питній воді (контроль);

- зразок №2 - сусло на воді, обробленій у послідовності клиноптилоліт, активне вугілля, гірський кришталь;

- зразок №3 - сусло на воді, обробленій у послідовності активне вугілля, клиноптилоліт, гірський кришталь;

- зразок №4 - сусло на воді, обробленій у послідовності гірський кришталь, клиноптилоліт, активне вугілля.

Сусло готували шляхом внесення концентрату квасного сусла у воду до концентрації сухих речовин $2,2 \ldots 2,3 \%$. Після цього цукровим сиропом доводили вміст сухих речовин до $3,2 \ldots 3,5 \%$. У готове сусло вносили чисту культуру дріжджів Saccharomyces cerevisiae МП-10 у кількості 1\% від об'єму сусла. Сусло зброджували при різних температурах до зменшення вмісту сухих речовин на $0,8 \ldots 1,0 \%$. При цьому тривалість бродіння становила $13 \ldots 19$ год. Із збродженого сусла видаляли осад і купажували цукровим сиропом.

Оптимальну температуру бродіння визначали на квасному суслі з початковою концентрацією сухих речовин $3,5 \%$. Сусло зброджували при температурах $28,30,32,34,36,38^{\circ} \mathrm{C}$ до зменшення концентрації сухих речовин у кожному зразку на $1,0 \%$.

Таблиия 1. Вплив температури на тривалість зброджування квасного сусла

\begin{tabular}{|c|c|c|c|c|c|c|}
\hline \multirow{2}{*}{ № зразка } & \multicolumn{7}{|c|}{ Температура бродіння, ${ }^{\circ} \mathrm{C}$} \\
\cline { 2 - 7 } & 28 & 30 & 32 & 34 & 36 & 38 \\
\cline { 2 - 7 } & \multicolumn{7}{|c|}{ Тривалість бродіння, год } \\
\hline 1 (контроль) & 19 & 17 & 16 & 15 & 15,5 & 17 \\
\hline 2 & 17 & 15 & 14 & 13 & 13,5 & 15 \\
\hline 3 & 18 & 16 & 15 & 14 & 14,5 & 16 \\
\hline 4 & 18 & 16 & 15 & 14 & 14,5 & 16 \\
\hline
\end{tabular}


Встановлено, що необхідне зниження вмісту сухих речовин у дослідних зразках, якщо порівняти 3 контролем, відбувалось на 2 год швидше при всіх досліджених температурах бродіння. Найбільш інтенсивно - при температурі $34^{\circ} \mathrm{C}$ для всіх зразків (13...15 год.). Зменшення та збільшення температури бродіння призводило до подовження процесу.

При порівнянні дослідних зразків із контролем визначено, що вода, оброблена досліджуваними матеріалами, суттєво впливала на процес бродіння. Так, для зразків $2 \ldots 4$, якщо порівняти 3 контролем, тривалість бродіння скоротилась в середньому на $13,3 \%$.

Отже, використання клиноптилоліту, гірського кришталю й активного вугілля при підготовці води дає змогу скоротити процес зброджування квасного сусла. Оптимальною температурою бродіння для дослідних зразків при використанні дріжджів Saccharomyces cerevisiae MП-10 є $32 \ldots 36^{\circ} \mathrm{C}$.

Динаміка зниження вмісту сухих речовин при зброджуванні дослідних зразків сусла за температури $34^{\circ} \mathrm{C}$ наведена на рис. 1 .

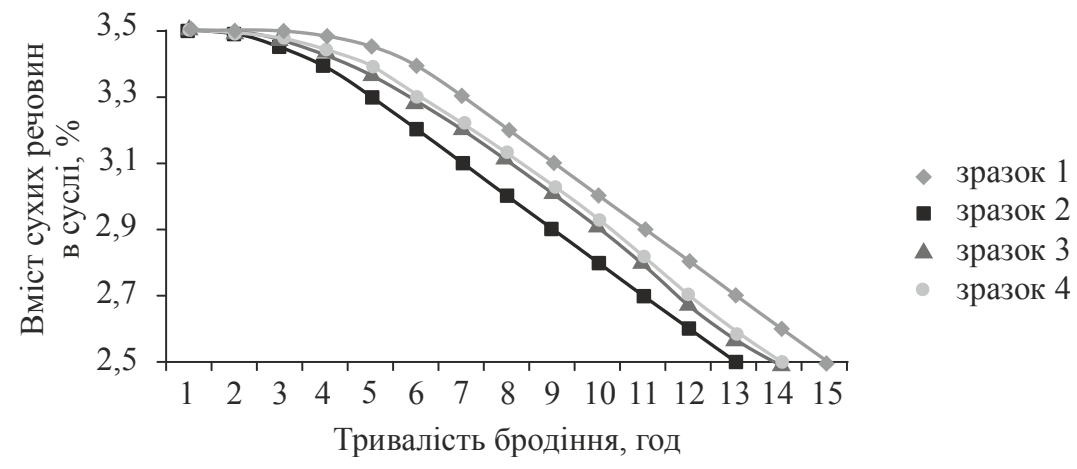

Рис. 1. Вплив підготовленої води на динаміку зниження вмісту сухих речовин при зброджуванні квасного сусла

Встановлено, що завдяки зміні мінерального складу води у всіх дослідних зразках, порівняно з контролем, зброджування сусла відбувалось більш інтенсивно. Так, у зразках 2, 3 і 4 зниження вмісту сухих речовин почалось після перших двох годин бродіння, а в контрольному зразку - після трьох. Це свідчить про позитивний вплив складу води, обробленої досліджуваними матеріалами на фізіологічний стан дріжджів. При цьому суттєво скорочувалась тривалість адаптації дріжджів до умов середовища i, відповідно, лаг-фаза їх розвитку. Суттєвих відмінностей у динаміці бродіння дослідних зразків між собою не спостерігали.

При проведенні досліджень встановлено також, що оброблена вода не тільки впливала на тривалість бродіння, але й на зовнішній вигляд напоїв. На рис. 2 наведена мутність отриманих зразків квасу. Додатково (зразок 5) дана мутність квасу, приготовленого на непідготовленій воді при використанні хлібопекарських дріжджів.

Встановлено, що підготовка води з використанням досліджуваних матеріалів позитивно впливала на зменшення мутності готового напою - на $5 \%$ порівняно з першим зразком і на $11 \%$ із п'ятим зразком, що можна пояснити 
зниженням вмісту гідрокарбонатів кальцію і магнію, які утворюють комплексні сполуки і викликають помутніння напою.

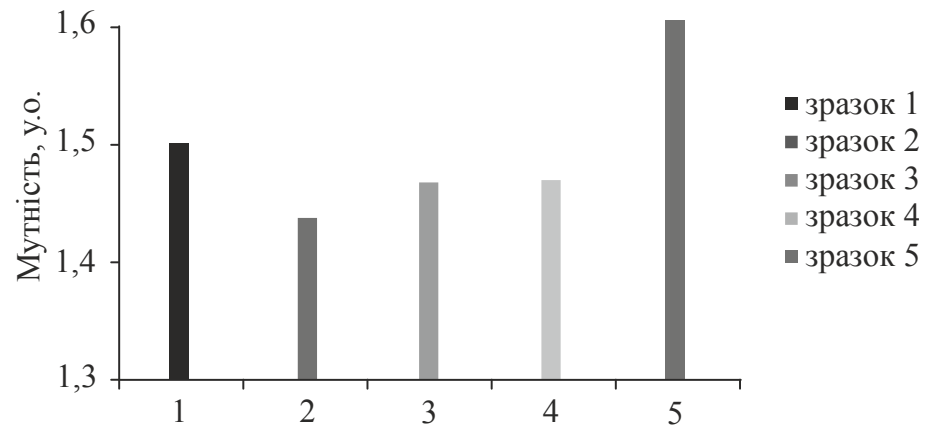

Рис. 2. Вплив підготовленої води на показник мутності квасу

Одним із факторів, що визначають фізіологічну активність дріжджів, $\epsilon$ кислотність середовища, зокрема активна, яка повинна бути 4,5 ..5,5. Величина рН впливає на інтенсивність обмінних процесів у клітині, приріст біомаси, швидкість росту і направленість самого бродіння. Від активної кислотності залежить потрапляння поживних речовин у клітину та швидкість ферментативних процесів.

У табл. 2 та на рис. 3 наведені значення кислотності початкового сусла $\mathrm{i}$ квасу та динаміка зміни титрованої кислотності у процесі бродіння.

\section{Таблиия 2. Кислотність сусла та квасу}

\begin{tabular}{|c|c|c|c|c|}
\hline \multirow[b]{2}{*}{ № зразка } & \multicolumn{2}{|l|}{ Кислотність сусла } & \multicolumn{2}{|l|}{ Кислотність квасу } \\
\hline & $\begin{array}{c}\text { Титрована кислотність, см } \\
\text { розчину NaOH конц. } \\
1 \text { моль/дм }{ }^{3} \text { на } 100 \mathrm{~cm}^{3} \text { сусла }\end{array}$ & $\mathrm{pH}$ & $\begin{array}{c}\text { Титрована кислотність, см } \\
\text { розчину } \mathrm{NaOH} \text { конц. } \\
1 \text { моль/дм } \\
13 \text { на } 100 \mathrm{~cm}^{3} \text { квасу }\end{array}$ & $\mathrm{pH}$ \\
\hline $\begin{array}{c}1 \\
(\text { контроль) }\end{array}$ & 0,9 & 5,94 & 1,15 & 5,59 \\
\hline 2 & 1,2 & 5,45 & 1,55 & 4,54 \\
\hline 3 & 1,18 & 5,52 & 1,50 & 4,56 \\
\hline 4 & 1,15 & 5,56 & 1,48 & 4,58 \\
\hline
\end{tabular}

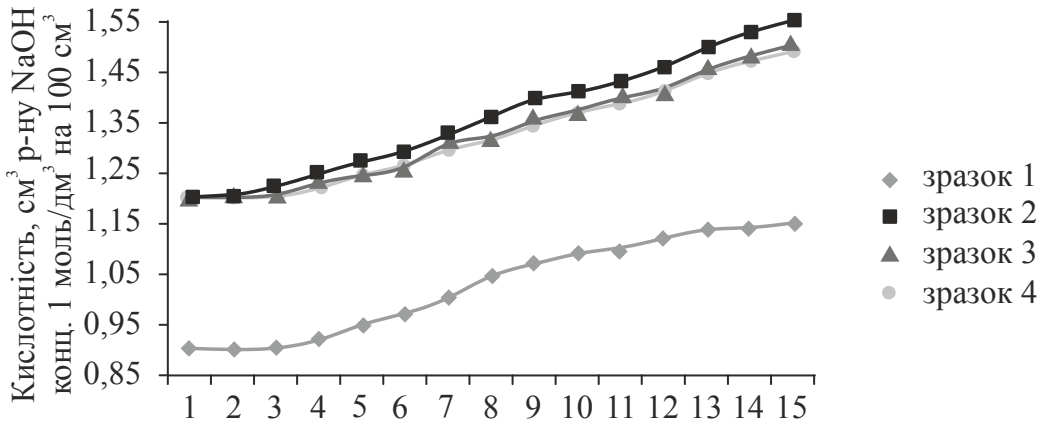

Тривалість бродіння, год

Рис. 3. Динаміка зміни титрованої кислотності квасного сусла в процесі бродіння 
Встановлено, що контрольний зразок мав найбільшу активну кислотність сусла $(\mathrm{pH} 5,94)$ та найнижчу титровану кислотність, що значно перевищувало оптимальне значення для здійснення дріжджами спиртового бродіння. Це безпосередньо пов'язано з використаною водою, у якої були найвищі показники загальної жорсткості і лужності.

Наростання кислотності квасного сусла у всіх зразках не досягло необхідних нормативних значень $\left(2 \ldots 4 \mathrm{~cm}^{3}\right.$ розчину $\mathrm{NaOH}$ конц. 1 моль/дм ${ }^{3}$ на $100 \mathrm{~cm}^{3}$ середовища). Це пояснюється тим, що процес бродіння відбувався тільки за участі дріжджів, а при спиртовому бродінні органічні кислоти утворюються у невеликій кількості, зокрема молочна — як проміжний продукт гідролізу фосфогліцеринового альдегіду. Отже, при купажуванні квасу контрольного зразка потрібно в середньому на $23,5 \%$ більше молочної або лимонної кислоти, якщо порівняти $з$ дослідними зразками.

Квас має наближене до фізіологічних потреб людини значення окисно-відновного потенціалу (ОВП), що пояснюється наявністю природних антиоксидантів у його складі - фенольних сполук і вітамінів. При виробництві напоїв значення ОВП не регламентується, однак при їх вживанні відіграє важливу роль в організмі людини. Напої з ОВП близьким до клітин організму людини краще засвоюються i, відповідно, мають біологічну сумісність. При цьому заощаджується енергія клітинних мембран на корекцію активності електронів.

На рис. 4 наведено ОВП води, сусла в процесі бродіння та готового квасу, приготовленого на різних зразках води.

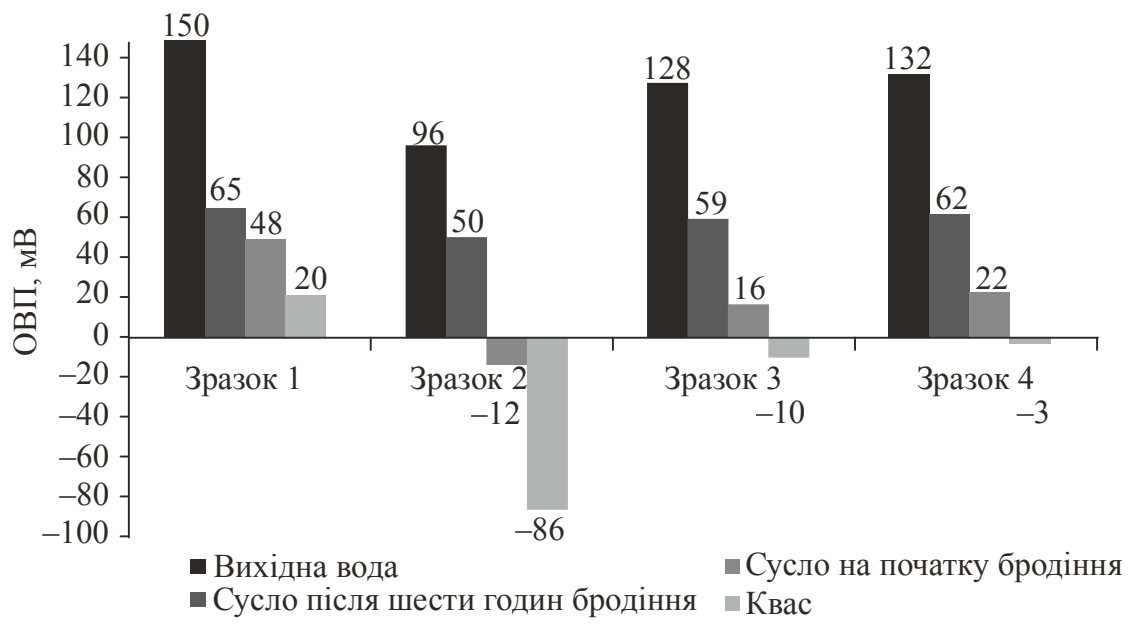

Рис. 4. Зміна окисно-відновного потенціалу на різних стадіях приготування квасу

Встановлено, що використання досліджених матеріалів при підготовці води для приготування хлібного квасу дало змогу суттєво знизити окисно-відновний потенціал води (на $54 \mathrm{mB}$ ) та готового продукту (на $106 \mathrm{MB}$ ) і наблизити його до оптимальних для клітин організму людини значень - від -100 мВ до -200 мВ [10-13]. Найменше значення ОВП спостерігали при обробці води у послідовності клиноптилоліт, активне вугілля, гірський кришталь. 


\section{Висновки}

1. Використання природних мінералів та активного вугілля при підготовці води дає змогу скоротити процес зброджування квасного сусла в середньому на 13,3\% та мутність готового напою на $5 . . .11 \%$.

2. Для дослідних зразків визначена оптимальна температура бродіння сусла $-32 \ldots 36^{\circ} \mathrm{C}$ при використанні дріжджів Saccharomyces cerevisiae MП-10.

3. При підготовці води для виробництва хлібного квасу вихідну воду доцільно обробляти природними матеріалами у послідовності кліноптилоліт, активне вугілля, гірський кришталь. При цьому досягається максимальне зниження окисно-відновного потенціалу води та готового продукту.

\section{Лiтература}

1. Технологія безалкогольних напоїв: підруч. / В.Л. Прибильський, 3.М. Романова, В.М. Сидор та ін.; за ред. докт. техн. наук, проф. В.Л. Прибильського. - Київ : НУХТ, 2014. $-312 \mathrm{c}$.

2. Інноваційні технології продуктів бродіння і виноробства: підруч. / С.В. Іванов, В.А. Домарецький, В.Л. Прибильський та ін. // За заг. ред. д-ра хім. наук, проф. С.В. Іванова. — Київ : НУХТ, 2012. - $487 \mathrm{c}$.

3. Наукове обгрунтування технології функціональних напоїв на основі пряно-ароматичних рослин [Електронний ресурс]. — Портал харчової промисловості «Харчовик» 16.05.2007p. — Режим доступу : http://www.harchovyk.com/content/detail/13).

4. На полицях - здорова їжа! [Електронний ресурс]: Портал харчової промисловості «Харчовик» - 25.06.2010p. — Режим доступу : http://www.harchovyk.com/ru/content/detail $/ 366$

5. Орлова В.О. Водоочистні фільтри із зернистою засипкою / В.О. Орлова - Рівне : НУВГП, 2005. - $163 \mathrm{c}$.

6. Митченко, T. Сегодня и завтра водоподготовки / Т. Митченко // Вода и водоочистные технологии. — 2015. — № 4(78). - С. 4-10.

7. Tokuno S. Granular Activated Carbon Filtration and Nitrification // Water Utilities Laboratory for the City of Corpus Christi Texas. - 2000. - \# 12. - P. 1-52.

8. Активне вугілля у водоготуванні для виготовлення напоїв / С.І. Олійник, В.Л. Прибильський, А. М. Куц та ін. // Харчова наука та технологія. — 2014. — № 3(28). - С. 36-42.

9. Цеолиты - минералы XXI века / Сантехника, отопление, кондиционирование, 2004. 一№ 4. - С. 50 - 52 .

10. Williams J. B., Williams L., Baldwin N. et al. Proc. Nat. Conf. on Environ. Sci. and Technol. (Greensboro, N.C., September 8-10, 2002). — Columbus (Ohio): Richland Battelle, 2003. - P. $91-98$.

11. Tremblay C.V., Beaubien A., Charles P.N. James A. Water Sci. and Technol. — 1998. 38, \# 6. - P. 121-128. 2007.

12. Oxidation-reduction potential (ORP)/REDOX, Application Bulletin, Myrol L. Company,

13. Suslow T.V. Introduction to ORP as the standard of postharvers water disinfection monitoring, US Davis Vegetable Research and Information Center. - http://vric.ucdavis.edu/veginfo/foodsafety/orp.pdf. 